\title{
Microarray Analysis of the Gene Expression Profile Induced by the Endophytic Plant Growth-Promoting Rhizobacteria, Pseudomonas fluorescens FPT9601-T5 in Arabidopsis
}

\author{
Yanqing Wang, Yumiko Ohara, Hitoshi Nakayashiki, Yukio Tosa, and Shigeyuki Mayama \\ Laboratory of Plant Pathology, Graduate School of Science and Technology, Kobe University, Rokkodai, Nada-Ku, \\ Kobe 657-8501, Japan
}

Submitted 21 June 2004. Accepted 6 January 2005.

Pseudomonas fluorescens FPT9601-T5 was originally identified as an endophytic plant growth-promoting rhizobacteria (PGPR) on tomato. To perform a molecular dissecttion of physiological and biochemical changes occurring in the host triggered by $P$. fluorescens FPT9601-T5 colonization, the model plant Arabidopsis was used in this study. Root colonization of Arabidopsis with $P$. fluorescens FPT9601-T5 promoted plant growth later than three weeks after inoculation and partially suppressed disease symptoms caused by Pseudomonas syringae pv. tomato DC3000, indicating that $P$. fluorescens FPT9601-T5 acted as a PGPR on Arabidopsis. To obtain a global view on transcript modification during the Arabidopsis-FPT9601T5 interaction, we performed microarray analysis using Affymetrix Genechip probe arrays representing approximately 22,800 genes. The results showed that 95 and 105 genes were up- or down-regulated, respectively, more than twofold in FPT9601-T5-treated Arabidopsis plants as compared with control plants. Those up-regulated included genes involved in metabolism, signal transduction, and stress response. Noteworthy, upon FPT9601-T5 colonization, putative auxin-regulated genes and nodulin-like genes were up-regulated, and some ethylene-responsive genes were down-regulated. Our results suggest that $P$. fluorescens FPT9601-T5 triggered plant responses in a manner similar to known PGPR and, at least in some aspects, to rhizobia.

Disease management through biological agents has attracted attention as an alternative strategy that is ecologically mild and environmentally safe. It has been shown that selected rhizobacteria enhance plant growth and yield with the ability to control soilborne pathogens (Glick 1994; Timmusk and Wagner 1999). A group of bacteria that display such effects are called plant growth-promoting rhizobacteria (PGPR). PGPR exhibit biocontrol activity by antagonistic interactions between the biocontrol agent and the pathogen as well as by stimulation of the host defense mechanism. The antagonistic interaction can involve the production of various antibiotic compounds or iron chelatore that inhibit the growth of soilborne pathogens and competition for nutrients and colonization sites at the root surface between the pathogen and biocontrol agent (Bakker et

Corresponding author: H. Nakayashiki; Telephone: +81-78-803-5867; Fax: +81-78-803-5867; E-mail: hnakaya@kobe-u.ac.jp al. 2003; Handelsman and Stabb 1996; Schippers 1992; Thomashow and Weller 1995).

P. fluorescens FPT9601-T5 is a commercial PGPR in Japan (Taki Chemical, Kakogawa), which was originally isolated from tomato rhizosphere. The colonization of tomato roots by the PGPR enhances plant growth and suppresses soilborne diseases such as tomato bacterial wilt caused by Ralstonia solanacearum (Aino et al. 1997). It has also been shown that $P$. fluorescens FPT9601-T5 acts as a biocontrol agent of soilborne diseases on a wide range of vegetable plants, including eggplant, green pepper, cucumber, squash, and Chinese cabbage (M. Aimo, Y. Maekawa, and S. Mayama, unpublished data). Production of two antibiotics (DAPG [2,4-diacetylphloroglucinol] and hydrogen cyanide), uncharacterized siderophores, and proteases by the PGPR has been found and has been shown to correlate with the growth inhibition against $R$. solanacearum in vitro (Zhang et al. 2000). Ultramicroscopic and laser-microscopic observation revealed that $P$. fluorescens FPT9601-T5 was found in the intercellular space of tomato roots as well as on the root surface. Therefore, this bacterium seems to endophytically colonize the roots of tomato in addition to surface colonization.

In several plant-PGPR combinations, colonization of roots with PGPR leads to a state of induced resistance not only in the colonized roots but also in the whole plant. This phenomenon is designated as induced systemic resistance (ISR). ISR has been reported in various plant species (e.g., Arabidopsis thaliana, common bean, carnation, cucumber, tobacco, tomato) that are colonized mostly by fluorescent Pseudomonads (Van Loon et al. 1998). The mechanisms leading to ISR seem to be highly dependent on the bacterial partners. P. fluorescens WCS417r, one of the most frequently studied PGPR on Arabidopsis, elicited ISR via a salicylic acid (SA)-independent pathway without pathogenesis-related (PR) gene activation (Pieterse et al. 1996, 1998; Van Wees et al. 1997). P. fluorescens WCS417r-induced ISR, however, required responsiveness to the plant hormones jasmonic acid (JA) and ethylene (ET) (Pieterse et al. 1998). Similarly, another P. fluorescens strain, CHA0, was shown to induce ISR in a SA-independent and JAdependent manner. However, P. fluorescens CHA0 triggered ISR even in certain Arabidopsis ethylene-insensitive mutants (ein 2-1 and etr 1-1), suggesting that the signaling pathway triggered by $P$. fluorescens $\mathrm{CHA} 0$ was at least partly different from that triggered by $P$. fluorescens WCS417r. In addition, a crucial role of DAPG in P. fluorescens CHA0-meditated ISR induction was shown, using its DAPG-deficient mutants (Iavicoli et al. 2003). In contrast to the above two PGPRs, 
some rizobacteria have been shown to induce systemic resistance via a SA-dependent pathway. $P$. aeruginosa $7 \mathrm{NSK} 2$ induced systemic resistance in tobacco in a SA-dependent manner without inducing PR1a expression (De Meyer et al. 1999). In addition, systemic resistance induced by Paenibacillus polymyxa was associated with up-regulation of SA-, JA-, and ET-responsive genes (Timmusk and Wagner 1999), indicating involvement of signaling through SA-, JA-, and ET in $P$. polymyxa-mediated systemic resistance. To know signaling pathways that were commonly involved in those phenomena induced by different species of PGPRs, comparison of genome-wide gene expression profiles rather than examination of a limited number of known genes could be a better approach.

Besides plant-PGPR interactions, root nodulation is a wellknown symbiotic phenomenon between plants and microorganisms in the rhizosphere, in which host plants provide the carbon source and energy for nitrogen-fixing bacteroids and, in turn, utilize the fixed nitrogen. A group of soil bacteria that have the ability to produce nodules on the roots of leguminous plants are collectively called rhizobia (Van Rhijn and Vanderleyden 1995). This symbiotic relationship requires a series of highly regulated and coordinated events in which signal molecules from both leguminous plants and rhizobia play important roles for recognizing each other. The infection of legume roots by rhizobia induces the expression of a set of host genes, termed nodulin during nodule formation. An interesting common feature between endophytic PGPR and rhizobia is that their infection into root tissue does not provoke plant defense reactions normally induced by invading microorganisms (Hungria and Stacey 1997). Therefore, plant responses that are commonly observed in interactions with the different types of symbiotic microorganisms are of great interest, since the responses may be related to a fundamental process for establishing symbiotic relationship between plants and microorganisms.

In this study, we performed microarray analysis using the model plant Arabidopsis to gain insights into physiological and biochemical changes in the host plant induced by the endophytic PGPR P. fluorescens FPT9601-T5. The results showed that approximately 200 out of 22,810 Arabidopsis genes on the microarray were identified as expressed differently (twofold change as the threshold) in FPT9601-T5-treated Arabidopsis plants. The majority of these genes fell into functional categories, such as basic metabolisms, signal transduction, and stress (defense) response. Predicted physiological changes in the host plant by FPT9601-T5 colonization are discussed.

\section{RESULTS}

P. fluorescens FPT9601-T5 promoted Arabidopsis growth and partially suppressed disease symptoms in leaves infected with $P$. syringae pv. tomato DC 3000 .

The model plant Arabidopsis provides many advantages for genetic dissection, including its small size, rapid life cycle, public databases for the genome sequence and gene information, and a rich source for mutants. In this study, we attempted to use Arabidopsis to dissect the molecular mechanisms involved in growth promotion and systemic resistance induced by $P$. fluorescens FPT9601-T5. We first examined the colonization of P. fluorescens FPT9601-T5 on Arabidopsis (Col-1). The density of the FPT9601-T5 strain endophytically colonized in Arabidopsis roots was monitored by taking advantage of the fact that the bacterium had both ampicillin (Amp) and streptomycin (Str)-resistant phenotypes. Five weeks after inoculation with $P$. fluorescens FPT9601-T5, bacterial population in Arabidopsis root tissues was assessed using media supplied with ampicillin and streptomycin. The results showed that $\mathrm{Amp}^{+}$and Str-resistant bacteria was recovered from the roots treated with $P$. fluorescens FPT9601-T5 at the density of $2.4 \times 10^{5} \pm 1.0 \times 10^{5} \mathrm{CFU} / \mathrm{g}$, but no bacteria was recovered from roots of control untreated plants, indicating that the FPT9601-T5 strain grew in Arabidopsis roots. When a green fluorescent protein (GFP)-tagged FPT9601-T5 strain was used for inoculating Arabidopsis, blight GFP fluorescence indicating bacteria colonies was detected on the root surface under a fluorescence microscopy (data not shown). Therefore, the FPT9601-T5 strain had the capacity of surface colonization on Arabidopsis roots as well as endophytic colonization.

Next, we assessed the plant growth promoting activity of $P$. fluorescens FPT9601-T5 on Arabidopsis. Arabidopsis plants inoculated with $P$. fluorescens FPT9601-T5 showed slower growth than control plants one week after inoculation (Fig. 1). However, later than four weeks after inoculation, slightly more growth was observed with FPT9601-T5-treated Arabidopsis

Table 1. Effects of Pseudomonas fluorescens FPT9601-T5 colonization on growth of Arabidopsis plants

\begin{tabular}{lcc}
\hline Treatment & Number of leaflets & Fresh weight (g/leaflet) \\
\hline FPT9601-T5 & $25.18 \pm 5.55$ & $0.725 \pm 0.18^{\mathrm{a}}$ \\
Control & $22.82 \pm 2.48$ & $0.559 \pm 0.12$ \\
\hline
\end{tabular}

a Significant difference by $t$ test (5\%).

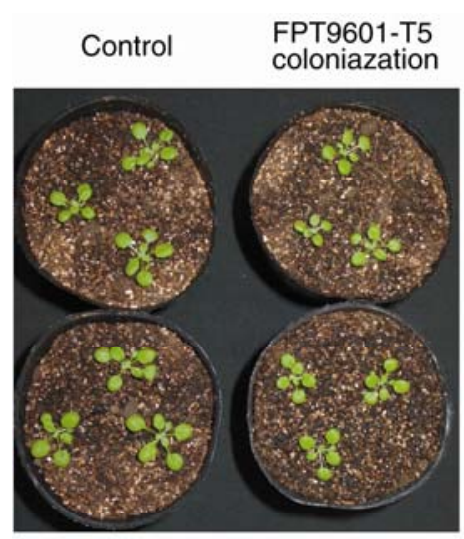

7 days ( 1 week)

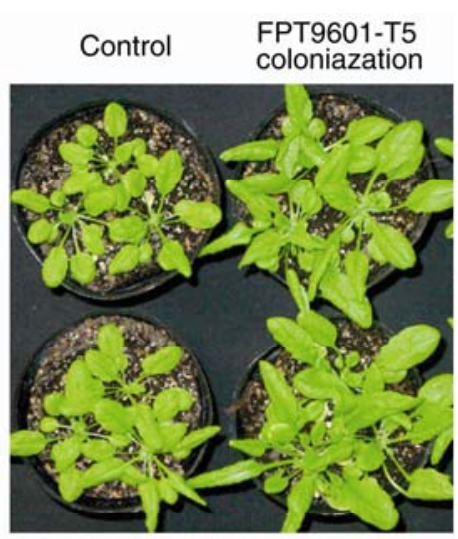

35 days (5 week)

\section{Days after inoculation}

Fig. 1. Effects of Pseudomonas fluorescens FPT9601-T5 colonization on growth of Arabidopsis plants. Photographs of bacterized Arabidopsis plants with P. fluorescens FPT9601-T5 at one and five weeks after inoculation. 
plants as compared with control plants (Fig. 1). When the number of leaflets and the fresh weight of Arabidopsis shoots were measured five weeks after $P$. fluorescens FPT9601-T5 treatment, about three more leaflets and significantly greater fresh weight (an average of $0.76 \mathrm{~g} / \mathrm{shoot}$ ) than in control plants $(0.50 \mathrm{~g} /$ shoot $)$ were observed in the treated plants (Table 1$)$.

A

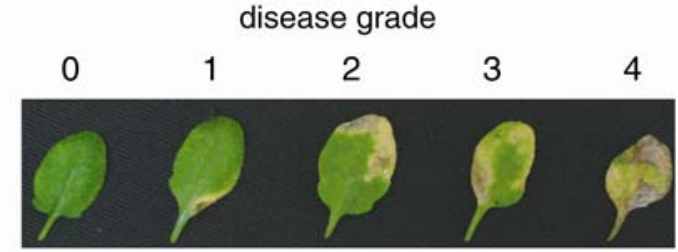

B

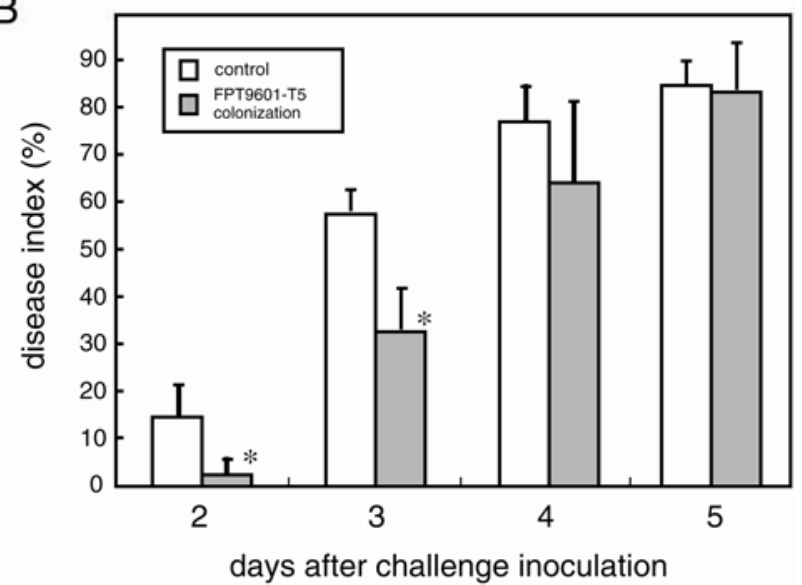

Fig. 2. Pseudomonas fluorescens FPT9601-T5 colonization triggered partially effective systemic resistance against challenge infection of $P$. syringe pv. tomato DC3000 in Arabidopsis plants. A, Based on the area with visible symptoms in a leaflet, the following five disease grades were used to assess the severity of $P$. syringae infection in Arabidopsis: 0, no symptom; $1=$ symptoms in $\leq 10 \% ; 2=10$ to $50 \% ; 3=>50 \%$; and $4=$ $100 \%$. B, The disease index was calculated with the following equation: disease index $(\%)=[(\mathrm{N} 0 \times 0+\mathrm{N} 1 \times 1+\mathrm{N} 2 \times 2+\mathrm{N} 3 \times 3+\mathrm{N} 4 \times) /(4 \times$ $(\mathrm{N} 0+\mathrm{N} 1+\mathrm{N} 2+\mathrm{N} 3+\mathrm{N} 4)] \times 100 ; \mathrm{N}=$ number of leaflets at each stage of disease grade. The disease index was scored 2, 3, 4, and 5 days after challenge-inoculation with at least five Arabidopsis plants.
Those results suggested that $P$. fluorescens FPT9601-T5 behaved as a PGPR on Arabidopsis, even though the bacterium suppressed plant growth in early stages of colonization. Interestingly, similar phenomena, suppression of plant growth in early stages and promotion of it in later stages, were also observed in tomato plants infected with $P$. fluorescens FPT9601T5 (data not shown). This may also correspond to growth suppression observed in Arabidopsis infected with $P$. thivervalensis MLG45 (Cartieaux et al. 2003).

Finally, we tested whether $P$. fluorescens FPT9601-T5 induced systemic resistance in Arabidopsis. Shoots of Arabidopsis plants whose roots had been inoculated with $P$. fluorescens FPT9601-T5 were challenge-inoculated with Pseudomonas syringae pv. tomato DC3000. Typically, Arabidopsis shoots develop bacteria speck disease symptoms consisting of necrotic or water-soaked spots surrounded by extensive chlorosis (Fig. 2A). We scored disease severity by determining the area of leaves with the symptoms. Figure $2 \mathrm{~B}$ shows that pretreatment of the FPT9601-T5 strain significantly reduced disease symptoms two and three days after challenge-inoculation. At four days after treatment, however, less difference in disease severity was observed between FPT9601-T5-treated and control plants, and no significant difference was found between the treated- and control plants later than five days after treatment (Fig. 2B). These results indicated that $P$. fluorescens FPT9601T5 had the ability to induce systemic resistance that was partially effective against challenge infection with $P$. syringae pv. tomato DC3000.

\section{Microarray analysis of gene expression} in Arabidopsis after inoculation with PGPR FPT9601-T5.

To obtain a global picture of gene expression changes triggered by colonization of $P$. fluorescens FPT9601-T5 in Arabidopsis, two independent microarray analyses were performed. To reduce experimental variation, three sets of nine shoots were harvested from $P$. fluorescens FPT9601-T5-treated and untreated plants, respectively, at three weeks after the treatment. Then, total RNA was prepared from the replicates of the pooled samples. RNA was analyzed using the Affymetrix GeneChip Arabidopsis array ATH1 containing 22, 810 Arabidopsis probe sets. The Affymetrix Microarray Suite software (MAS version 5.0) was applied for analyzing the reliability of signals for each probe set (Wang et al. 2003). Changes in expression

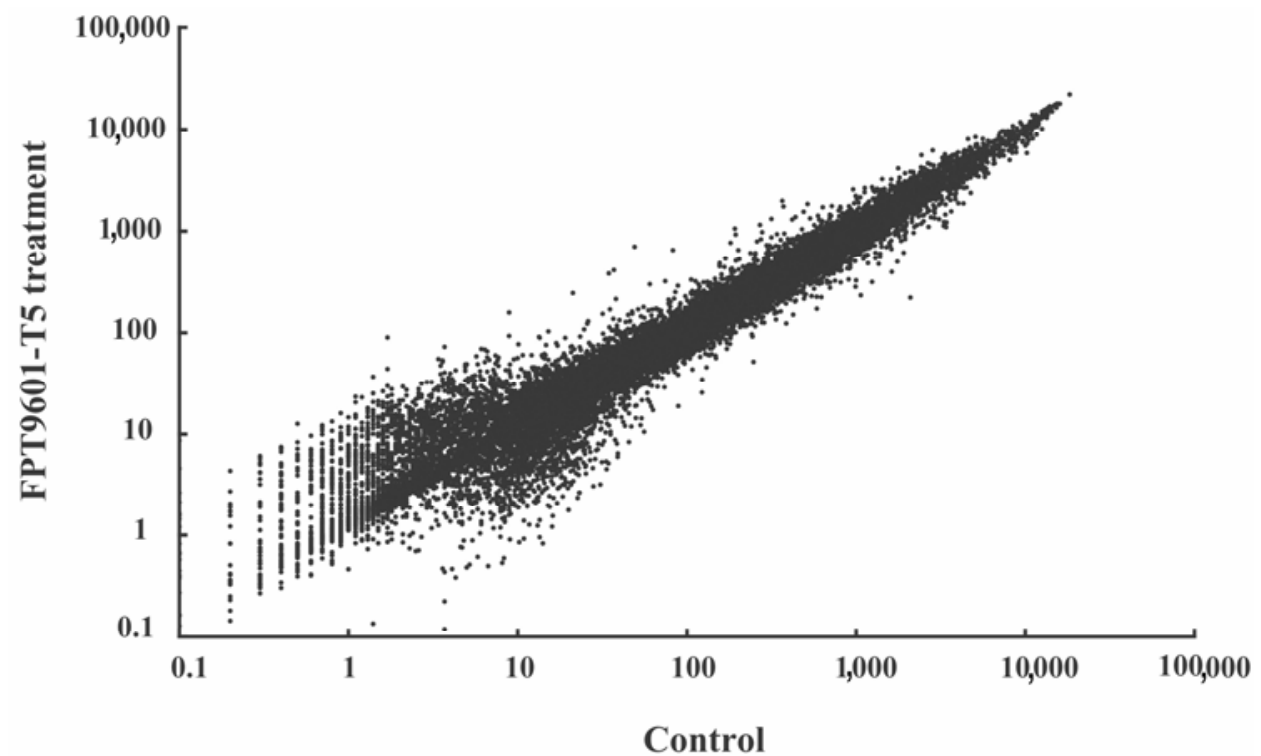

Fig. 3. A scatter plot of NetAffx microarray analysis with mRNA from Pseudomonas fluorescens T5-treated and untreated Arabidopsis plants. 
$27.62 \%$ of down-regulated genes), "transcription" (7.37\% of upregulated genes, $16.19 \%$ of down-regulated genes), "cellular communication/signal transduction mechanism" (4.2\% of upregulated genes, $3.81 \%$ of down-regulated genes), "cell rescue, defense, and virulence" ( $8.42 \%$ of up-regulated genes, $5.71 \%$ of down-regulated genes), "development" (including systemic and biogenesis of cellular components) $(7.35 \%$ of up-regulated genes), and "unclassified proteins" (including classification not yet clear-cut) (43.16\% of up-regulated genes, $30.48 \%$ of downregulated genes) (Fig. 4A).

The majority of the up-regulated genes seem to be related to two major biological changes induced by the bacterium in the host plant, growth promotion and elevated disease resistance. Possible genes involved in plant growth promotion are auxininduced genes (At4g36110, At2g33830), NAM-like genes (At2g17040, At5g39610, At1g69490, At3g04070), and those involved in C-compound and carbohydrate metabolism (e.g., $\beta$-galactosidase [At5g56870], xyloglucan endotransglycosylase-related protein [At4g14130], putative endoxyloglucan glycosyltransferase [At2g06850], xyloglucan endo-1,4- $\beta$-Dglucanase [At4g30270], UDP-glucose glucosyltransferase [At1g78270]), some of which are shown to be regulated by auxin in other plant species (Catala et al. 1997; Taguchi et al. 2001). Genes related to elevated disease resistance could be

Table 2. Continued from preceding page

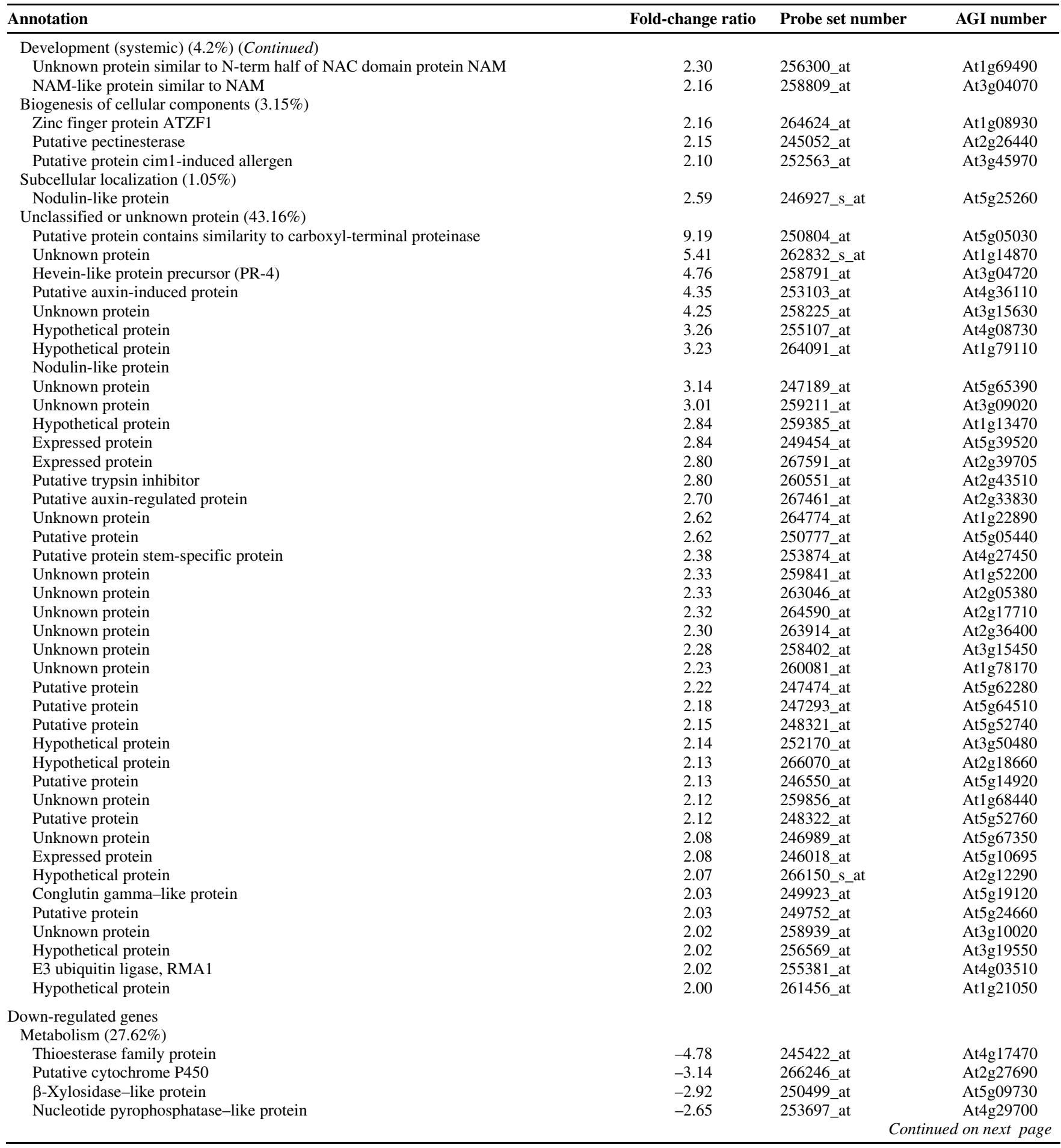


PR proteins (At2g43570, At3g04720, At3g57240, At3g57260), WRKY transcription factors (At2g30250), those involved in secondary metabolism (flavanone 3-hydroxylaselike protein [At5g24530], trans-caffeoyl-coenzyme A 3-O-methyltransferase [At1g67980], cytochrome P450 [At2g26710]), and stress response proteins such as glutathione S-transferase (At5g17220), drought-induced protein (At4g15910), peroxidase (At2g37130), and stress-responding small protein (At4g02380). Interestingly, four nodulin-like genes (At1g01070, At2g16660, At4g10380, and At5g25260) are up-regulated by $P$. fluorescens FPT9601-T5 treatment. Nodulin is a group of plant genes that are highly induced during nodule formation, and thus, are specifically expressed during plant-rhizobia inter- actions. This result suggested that endophytic PGPR and rhizobia might share a common signaling pathway and mechanism to establish the relationship with the host plant.

The two largest functional categories (except for unclassified protein) of the down-regulated genes are metabolism $(27.62 \%)$ and transcription (16.19\%) (Fig. 4B). The down-regulated genes belonging to the metabolism category mainly include those involved in carbohydrate and secondary metabolism, and those that belong to the transcription category largely comprise two major transcription factor families, ERF (ethylene-response factor)/AP2 (At1g74930, At2g22200, At2g44840, At4g34410, At5g47220) and Myb (At1g18710, At1g74430, At5g60890, At5g67300) (Table 2). Noteworthy, some parts of signaling

Table 2. Continued from preceding page

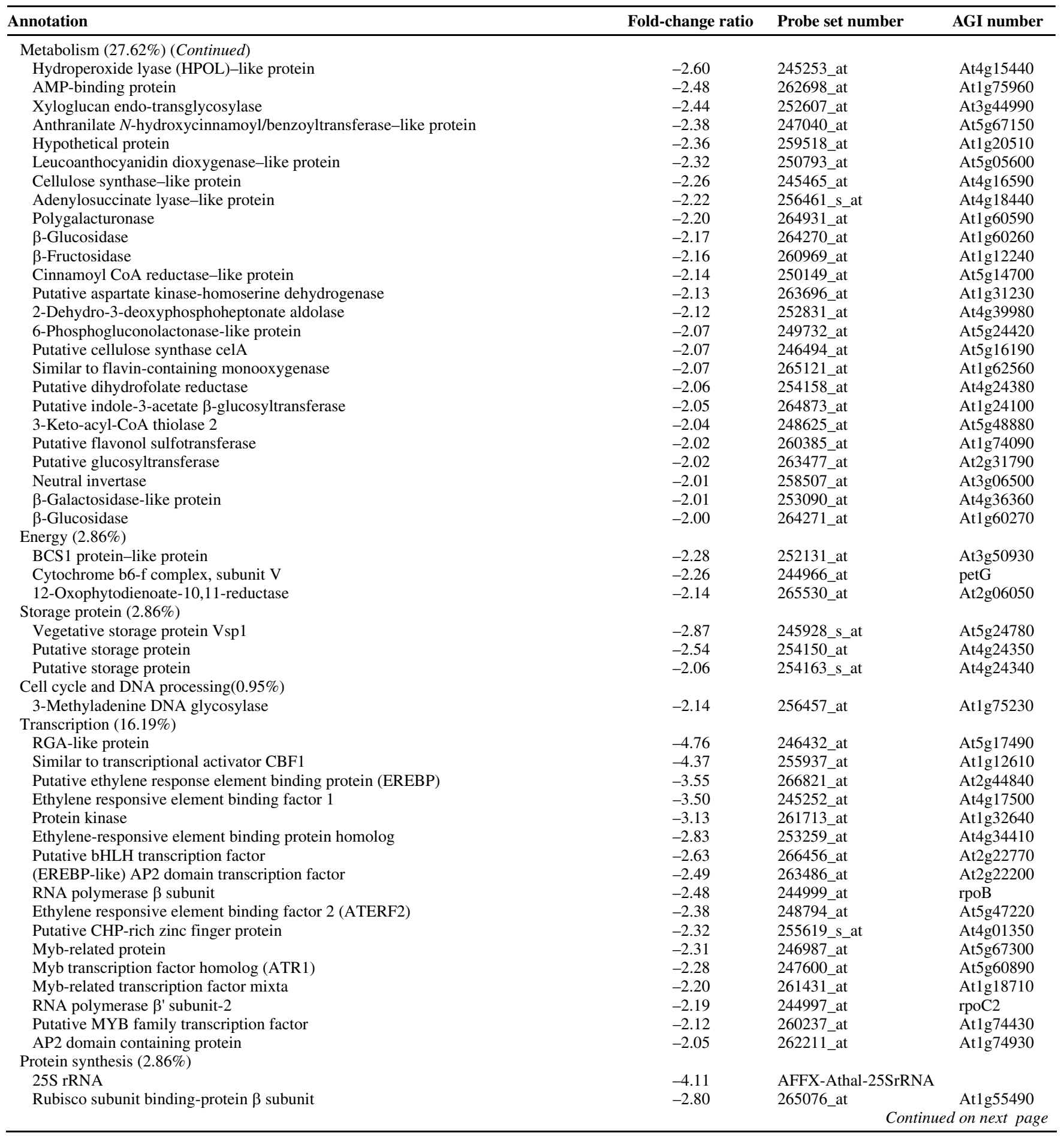


pathways related to plant defense seem to be suppressed during the Arabidopsis-P. fluorescens FPT9601-T5 interaction. For instance, genes involved in the ethylene signaling pathway, as mentioned above, and those involved in antimicrobial substance synthesis such as cinnamoyl CoA reductaselike protein (At5g14700) and anthranilate $N$-hydroxycinnamoyl/benzoyltransferaselike protein (At5g67150) were down-regulated.

\section{Reverse transcription-polymerase chain reaction (RT-PCR) analysis of representative genes.}

Since cross-hybridization from closely related members of the gene families may be a confounding factor in microarray experiments, RT-PCR analysis was carried out to verify the array hybridization data. RT-PCR assays were performed on 24 randomly selected genes, including up- and down-regulated genes identified in the microarray analysis. These RTPCR experiments used RNA from untreated and treated plants that were used for independent biological experiments from the microarray analysis. The PCR reaction with 25 cycles of amplification was analyzed by gel electrophoresis. The results of RT-PCR analysis mostly coincided with the expression profiles obtained through the microarray hybridization experiments. Thus the increased and decreased expression patterns of the microarray analysis were supported by RTPCR analyses. Examples in the RT-PCR analyses are shown in Figure 5.

Table 2. Continued from preceding page

\begin{tabular}{|c|c|c|c|}
\hline Annotation & Fold-change ratio & Probe set number & AGI number \\
\hline \multicolumn{4}{|l|}{ Protein synthesis $(2.86 \%)$ (Continued) } \\
\hline Similar to elongation factor $\mathrm{G}$ & -2.01 & 262645_at & At1g62750 \\
\hline \multicolumn{4}{|l|}{ Protein with binding function or cofactor requirement $(0.95 \%)$} \\
\hline Nodulin-like protein & -2.29 & 267044_at & At2g34350 \\
\hline \multicolumn{4}{|c|}{ Cellular transport, transport facilitation, and transport routes $(0.95 \%)$} \\
\hline Putative proline transporter & -2.21 & 263918_at & At2g36590 \\
\hline \multicolumn{4}{|c|}{ Cellular communication/signal transduction mechanism $(3.81 \%)$} \\
\hline Receptor-like kinase & -3.20 & 265030_at & At1g61610 \\
\hline Putative protein kinase & -2.54 & 267058_at & At2g32510 \\
\hline Inositol 1,3,4-trisphosphate 5/6-kinase-like protein & -2.12 & 255132_at & At4g08170 \\
\hline Receptor lectin kinase 3 & -2.10 & 251482_s_at & At3g59740 \\
\hline \multicolumn{4}{|l|}{ Cell rescue, defense, and virulence $(5.71 \%)$} \\
\hline Putative lipoxygenase & -4.59 & 260399_at & At1g72520 \\
\hline KED-like protein & -3.81 & 247649_at & At5g60030 \\
\hline Cytochrome P450 & -2.71 & 248353_at & At5g52320 \\
\hline Putative cytochrome $\mathrm{P} 450$ & -2.31 & 264052_at & At2g22330 \\
\hline Cytochrome P450-like protein & -2.01 & 252827_at & At4g39950 \\
\hline Polygalacturonase inhibiting protein & -2.01 & 250669_at & At5g06870 \\
\hline \multicolumn{4}{|l|}{ Transposable elements, viral, and plasmid proteins (1.9\%) } \\
\hline Putative polyprotein & -2.68 & 255333_at & At4g04410 \\
\hline En/Spm-like transposon protein & -2.49 & 262448_at & Atlg 49450 \\
\hline \multicolumn{4}{|l|}{ Subcellular localization $(2.86 \%)$} \\
\hline Putative annexin & -3.06 & 266418_at & At2g38750 \\
\hline Putative annexin & -2.51 & 266419_at & At2g38760 \\
\hline Mucin-like protein & -2.40 & 252114_at & At3g51450 \\
\hline \multicolumn{4}{|l|}{ Unclassified or unknown protein $(30.48 \%)$} \\
\hline Hypothetical protein & -9.50 & 266901_at & At2g34600 \\
\hline Hypothetical protein & -3.95 & 255604_at & At4g01080 \\
\hline Unknown protein & -3.52 & 256017_at & Atlg19180 \\
\hline Unknown protein & -3.41 & 261033_at & At1g17380 \\
\hline Hypothetical protein & -3.11 & 264289_at & At1g61890 \\
\hline Putative protein & -2.93 & 250960_at & At5g02940 \\
\hline Putative copper amine oxidase & -2.86 & 246573_at & At1g31680 \\
\hline Putative protein & -2.79 & 247933_at & At5g56980 \\
\hline Unknown protein contains similarity to chlorophyllase & -2.69 & 255786_at & Atlg19670 \\
\hline Hypothetical protein & -2.60 & 262661_s_at & Atlg14250 \\
\hline Hypothetical protein & -2.49 & 256655_at & At3g18890 \\
\hline Putative protein & -2.44 & 253849_at & At4g28080 \\
\hline Expressed protein & -2.43 & 262226_at & Atlg53885 \\
\hline Unknown protein & -2.34 & 256096_at & At1g13650 \\
\hline Unknown protein & -2.34 & 260429_at & Atlg72450 \\
\hline Hypothetical protein & -2.32 & 260205_at & At1g70700 \\
\hline Expressed protein & -2.31 & 267177_at & At2g37580 \\
\hline Expressed protein & -2.28 & 253758_at & At4g29060 \\
\hline Hypothetical protein & -2.28 & 251083_at & At5g01590 \\
\hline Putative copper amine oxidase & -2.21 & 246603_at & Atlg31690 \\
\hline Hypothetical protein & -2.19 & 259885_at & Atlg76380 \\
\hline Expressed protein & -2.19 & 253832_at & At4g27654 \\
\hline Unknown protein & -2.16 & 262171_at & Atlg74950 \\
\hline Putative membrane-associated salt-inducible protein & -2.16 & 253209_at & At4g34830 \\
\hline Putative monodehydroascorbate reductase & -2.14 & 260325_at & At1g63940 \\
\hline Putative protein & -2.12 & 248091_at & At5g55120 \\
\hline Unknown protein & -2.11 & 262577_at & At1g15290 \\
\hline Hypothetical protein & -2.09 & 267344_at & At2g44230 \\
\hline Unknown protein & -2.04 & 263972_at & At2g42760 \\
\hline Hypothetical protein & -2.01 & 258997_at & At3g01810 \\
\hline Unknown protein & -2.01 & 257717_at & At3g18390 \\
\hline Putative trypsin inhibitor & -2.00 & 260547_at & At2g43550 \\
\hline
\end{tabular}




\section{DISCUSSION}

Gene expression profiling through the use of microarrays has been recognized as a powerful approach to obtain a global view on gene expression and physiological processes involved in response to a particular stimulus (Maleck et al. 2000; Schenk et al. 2000). Based on genome-wide sequence information, oligonucleotide-based microarrays that provide the advantage of greater specificity and improved quantitative accuracy over spotted cDNA microarrays, have been developed especially in model organisms. One of the model organisms, Arabidopsis, offers an excellent experiment system in plant biology (Meinke et al. 1998). Using the Affymetrix Arabidopsis GeneChip probe array, we performed a global analysis of transcript modification associated with colonization by the endophytic PGPR, P. fluorescens FPT9601-T5. P. fluorescens FPT9601-T5 is commercially available as a biological control agent in Japan (Taki Chemical). The endophytic PGPR is currently registered as a biological pesticide only against tomato bacterial wilt disease caused by $R$. solancearum, but the effectiveness of the bacterium for controlling other soilborne diseases on a wide range of vegetable plants has already been shown at the experimental scale (M. Aimo, Y. Maekawa, and S. Mayama, unpublished data).

\section{Similarity in gene expression profiles}

of host plants treated with different types of rhizobacteria.

Cartieaux and associates (2003) conducted microarray analysis of Arabidopsis colonized by the PGPR P. thivervalensis MLG45 and reported transcript modifications of 63 genes in shoots and of nine genes in roots by the bacterial colonization. An increase of defense-related transcripts and a repression of photosynthesis-related transcripts by the colonization were reported as characteristic changes. Interestingly, some of the upregulated genes identified with $P$. thivervalensis MLG45 infection were also activated in the present microarray analysis with $P$. fluorescens FPT9601-T5. For instance, putative auxin-regulated protein (At2g33830), xyloglucan endo-1,4- $\beta$-D-glucanase precursor (At3g30270) and heat, auxin, ethylene, and wounding-induced small protein (At4g02380), all of which were reported to be related to auxin response, were commonly upregulated. Plant hormone plays important roles in plant devel- opment (Simon and Chua 1999). Auxin is implicated in a variety of plant developmental processes, including lateral root development and elongation of the hypocotyls. In tomato, the activation of the Cel7 endo-1, 4- $\beta$-D-glucanase was correlated with elongation of the hypocotyls induced by auxin treatment (Catala et al. 1997). Therefore, those genes may be involved in plant growth-promoting activity of the bacteria. Activation of $\beta$-galactosidase (At5g56870), seed imbibition protein (At5g20250), and conglutin gammalike protein (At5g19120) were also identified in both the microarray analyses with $P$. thivervalensis and P. fluorescens FPT9601-T5.

Recently, Verhagen and associates (2004) have reported transcriptome analysis of Arabidopsis plants colonized with the well-studied $P$. fluorescens strain WCS417r. In the analysis, 97 genes were identified as WCS417r-responsive genes in roots, but no detectable transcriptional changes were found in shoots, suggesting that systemic changes in gene expression were not induced throughout Arabidopsis plants upon local colonization of $P$. fluorescens WCS417r. Even though our microarray analysis was performed with mRNA from shoots, five genes were shown to be commonly responsive to the coloniza-

\begin{tabular}{|c|c|c|c|}
\hline \multirow{2}{*}{ ProbeSet ID } & \multirow{2}{*}{ MIPS code } & RT-PCR & \multirow{2}{*}{$\begin{array}{l}\text { Signal Ratio } \\
\log _{2}(\mathrm{~T} 5 / \mathrm{C})\end{array}$} \\
\hline & & $\begin{array}{ll}\mathrm{C} & \mathrm{T} 5\end{array}$ & \\
\hline 257832_at & At3g26740 & 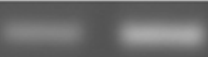 & 0.5 \\
\hline 246114_at & At5g20250 & 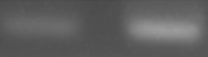 & 1.9 \\
\hline 265478_at & At2g15890 & $\therefore=$ & 1.2 \\
\hline 251341_at & At3g60770 & 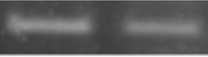 & -0.7 \\
\hline Actin & At $3 g 46520$ & $=$ & \\
\hline
\end{tabular}

Fig. 5. Reverse transcription-polymerase chain reaction analysis of mRNA expression of randomly selected genes based on the microarray results. C $=$ mRNA from control plants; T5 = mRNA from Pseudomonas fluorescens T5-treated plants.

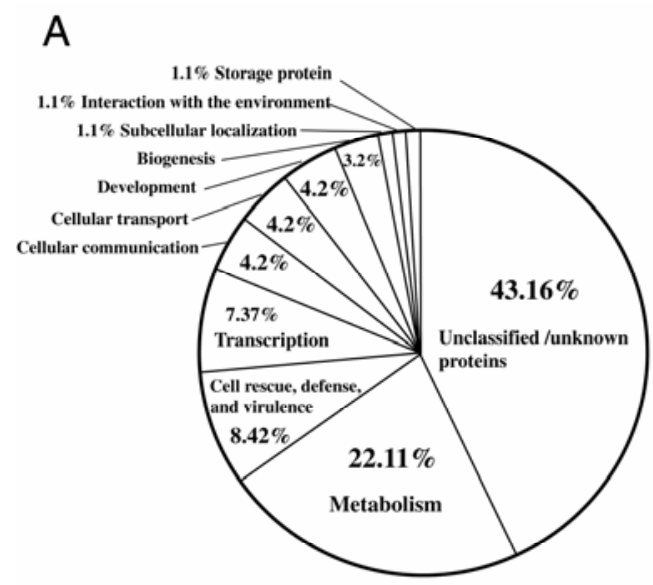

Up-regulated genes

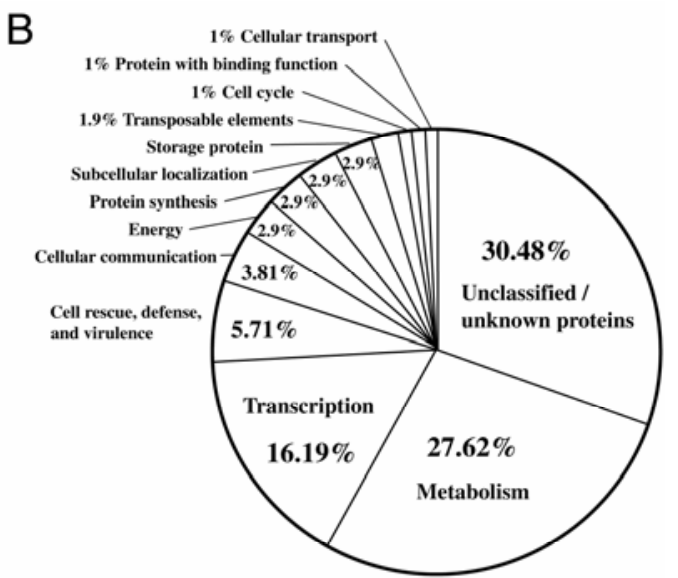

Down-regulated genes

Fig. 4. Pie charts showing the percentage of $\mathbf{A}$, up-regulated and $\mathbf{B}$, down-regulated genes in each of the functional categories. Biogenesis = biogenesis of cellular components; Cell cycle = cell cycle and DNA processing; Cellular communication = cellular communication/signal transduction mechanism; Cellular transport $=$ cellular transport/transport function and transport routes; Development $=$ development $($ systemic); Interaction with the environment $=$ interaction with the environment (systemic); Protein with binding function = protein with binding function or cofactor requirement; Transposable elements = transposable elements/viral and plasmid proteins. 
tion of two different $P$. fluorescens strains, WCS417r and FPT9601-T5. Those include up-regulation of two genes, drought-induced protein (At4g15910) and GAST1 protein homolog (AT1g75750), and down-regulation of three genes, ethylene-responsive element binding factor 1 and 2 (At4g17500, At5g47220) and myb-related protein (At5g67300). It is noteworthy that transcriptional changes induced by $P$. fluorescens FPT9601-T5 have some overlap with those induced by either P. fluorescens WCS417r or P. thivervalensis MLG45, whereas little overlap was observed between transcriptional changes induced by $P$. fluorescens WCS417r and $P$. thivervalensis MLG45. Therefore, P. fluorescens FPT9601-T5 may possess intermediate characteristics between $P$. fluorescens WCS417r and $P$. thivervalensis MLG45.

Our microarray analysis also suggested intriguing similarity between different types of rhizobacteria, endophytic PGPR, and rhizobia. Infection of leguminous plants with rhizobia induces up-regulation of a series of characteristic genes, designated nodulin genes. Even though biological roles of most nodulin genes still remain largely unknown, evidence is accumulating on involvement of certain nodulin genes in metabolite fluxes and morphological development of the host plants during legume-rhizobia interactions (Charon et al. 1997; Guenther et al. 2003). In the present study, four nodulin-like genes (At1g01070, At2g16660, At4g10380, At5g25260) were up-regulated upon infection with FPT9601-T5 in Arabidopsis. Three of the four nodulin-like genes (At1g01070, At2g16660, At4g10380) possess predicted transmembrane domains and motifs similar to transporter proteins. Interestingly, according to the information provided by MIPS, the molecular function of one of the nodulin-like genes (At2g16660) was predicted to be "endomembrane system" or "mating-type factor pheromone receptor activity" with amino acid sequence similarity to yeast G-protein-coupled receptor STE3. Therefore, the nodulin-like gene could be involved in signal perception or secretion during Arabidopsis- $P$. fluorescens FPT9601-T5 interactions, or those nodulin-like genes may be involved in enhancement of plant mineral and nutrient uptake induced by PGPR colonization as described previously (Bashan et al. 1989; Kapulnik 1996). It was also reported that some nodulin genes were activated in roots infected with another type of symbiotic microorganisms, vesicular arbuscular mycorrhizal fungi (Van Rhijn et al. 1997). In addition, endoparasitic nematode infection induced some nodulin genes in Medicago truncatula, even though the number of the induced nodulin genes was limited (Favery et al 2002). Thus, it might be possible that those endophytic microorganisms may have, at least in part, overlapping regulatory pathways to establish relationship between the host plants. Noteworthy, FPT9601-T5 colonization led to down-regulation of Arabidopsis genes involved in the ethylene signaling pathway as mentioned above. This may implicate another aspect of similarity between rhizobia and P. fluorescens FPT9601-T5, since certain rhizobia were shown to reduce plant ethylene levels during nodule formation (Ma et al. 2002).

\section{FPT9601-T5-induced transcriptional changes share overlap with, but appear \\ to be distinct in, plants expressing systemic acquired resistance (SAR) or ISR.}

Rhizobacterium-mediated ISR is a broad-spectrum resistance that is triggered by selected strains of nonpathogenic rhizosphere bacteria (Van Loon et al. 1998). Several approaches have been conducted to identify ISR-related gene expression (Cartieaux et al. 2003; Pieterse et al. 1996; Pieterse et al. 2000; Timmusk and Wagner 1999; van Wees et al. 1999; Verhagen et al. 2004). The expression pattern of a set of known defenserelated genes was analyzed upon ISR induction in Arabidopsis infected with $P$. fluorescens WCS417r. Of the many defenserelated genes examined (e.g., the SA-inducible genes $P R-1$, $P R-2$, and $P R-5$ and the ethylene- and JA-inducible genes $\mathrm{Hel}$, ChiB, Pdf1.2, Atvsp, Lox1, Lox2, and Pal1), none were found to be up-regulated in Arabidopsis inoculated with $P$. fluorescens WCS417r. Recent transcriptome analysis on $P$. fluorescens WCS417r-ISR in Arabidopsis further supported this conclusion (Verhagen et al. 2004). Interestingly however, their microarray analysis revealed that augmented expression of defenserelated genes, especially those regulated by ethylene and JA, were observed upon challenge-inoculation of the bacterial leaf pathogen $P$. syringae pv. tomato DC3000 in ISR-expressing leaves (Verhagen et al. 2004). This was consistent with their previous observation that the jasmonate-inducible gene Atvsp was up-regulated upon challenge-inoculation with the pathogen in ISR-expressing plants (van Wees et al. 1999). Therefore, in ISR-expressing plants, the expression of a set of defenserelated genes are not really induced at that state but seem to be primed to respond upon challenge infection, therefore leading to elevated disease resistance of the plant.

In this study, $P$. fluorescens FPT9601-T5-mediated systemic resistance in Arabidopsis was partially effective to challenge infection by $P$. syringae DC 3000 . The gene expression changes to support this partially effective systemic resistance induced by $P$. fluorescens FPT9601-T5 colonization seemed to be distinct from those reported in canonical ISR induced by $P$. fluorescens WCS417r but rather to share some overlap with those observed in SAR. SAR is another type of systemic disease resistance induced after local infection of a pathogen and is typically accompanied by an increase in the level of endogenous SA and subsequent PR protein expression (Ross 1961). In our microarray analysis, up-regulation of some PR proteins (At2g43570, At3g04720, At3g57240, At3g57260) and SARrelated genes, such as caffeoyl-coenzyme A 3-O-methyltransferase (At1g67980) (Busam et al. 1997), was observed. However, it should be noted that the number of induced defenserelated genes in our analysis was very limited compared with those usually observed in SAR-expressing plants (van Wees et al. 1999; Ward et al. 1991). In fact, by Northern analysis, we did not observe a local or systemic increase in the level of PR1 mRNA accumulation in P. fluorescens FPT9601-T5-treated plants (data not shown).

Interestingly, some positive transcription factors of ethyleneresponsive genes were down-regulated in Arabidopsis plants colonized by $P$. fluorescens FPT9601-T5 as well as by $P$. fluorescens WCS417r (Verhagen et al. 2004). Verhagen and associates (2004) postulated that the onset of ISR is associated with a reduction in ethylene signaling. If this is correct, the same signaling pathway associated with ISR is also likely to be primed by $P$. fluorescens FPT9601-T5 colonization. Thus, systemic induced resistance by $P$. fluorescens FPT9601-T5 may partly share signaling pathways with ISR induced by $P$. fluorescens WCS417r. In this context, it would be of interest to examine transcription profiles in P. fluorescens FPT9601-T5treated Arabidopsis plants upon challenge infection with a pathogen. In conclusion, transcriptional changes induced by $P$. fluorescens FPT9601-T5 in the host plant have some overlap with those reported in typical SAR- or ISR-expressing plants but appear to be significantly distinct from either of them.

\section{Genes associated}

with partially effective systemic resistance induced by $P$. fluorescens FPT9601-T5 in Arabidopsis.

The gene expression profile during systemic induced resistance by P. fluorescens FPT9601-T5 appeared to be somewhat puzzling, since both up- and down-regulation of possible defense-related genes were observed. Transcriptional up-regula- 
tion was detected in PR proteins, stress-related transcription factors (At4g34590, at2g30250), general stress responding genes (At2g37130, At4g02380, At4g15910, At5g17220), and those possibly involved in antimicrobial substance production (At1g67980, At2g26710, At5g24530), all of which can be related to disease defense response of the plant. Conversely, transcriptional down-regulation was also observed in possible defense-related genes, including lipoxygenase (At1g72520), which is a key enzyme in the jasmonate synthesis pathway, ERF transcription factors (At1g74930, At2g22200, At2g44840, At4g34410, At5g47220), positive regulators of ethylene-responsive genes including defense-related genes, and those reported to be involved in lignin or phytoalexin synthesis, such as cinnamoyl CoA reductase (At5g14700) and anthranilate $N$-hydroxycinnamoyl/benzoyltransferase (At5g67150) (Jones et al. 2001; Yang et al. 2004). It is attractive to postulate that $P$. fluorescens FPT9601-T5 may suppress some parts of defense signaling pathways of the host plant to facilitate its endophytic colonization. Actually, symbiotic rhizobia have been shown to have several mechanisms to suppress the activation of host defense (Bartsev et al. 2004; Mithöfer 2002). This negative effect on inducing disease resistance may make FPT9601-T5-mediated systemic resistance partially effective. Of note, even though systemic resistance induced by $P$. fluorescens FPT9601-T5 is partially effective, the bacterium shows high biocontrol ability of soilborne pathogens in a variety of plants. Therefore, the ability of the bacterium to biologically control pathogens may mainly depend on direct antibiotic effects of the bacterium against pathogens in soil.

\section{MATERIALS AND METHODS}

\section{Plant growth conditions.}

Seeds of $A$. thaliana ecotype Columbia (Col-0) were surfacesterilized by $70 \%$ ethanol and $\mathrm{NaClO}$ and were washed with distilled water. The seeds were sown on MS medium (Murashige and Skoog 1962), were laid in $4^{\circ} \mathrm{C}$ for two days as dormant releasing, and then, the MS petri dishes were placed in a growth chamber at $21^{\circ} \mathrm{C}$ with a photoperiod of $12 \mathrm{~h}$ of light and $12 \mathrm{~h}$ of dark. After a week, plants were replanted in potting soil and were maintained in the growth chamber. Plants were watered twice a week.

\section{Cultivation of bacteria.}

P. fluorescens was cultivated in King's B (KB) medium supplemented with streptomycin $(200 \mathrm{ug} / \mathrm{ml})$ and ampicillin $(50$ $\mathrm{ug} / \mathrm{ml}$ ) at $30^{\circ} \mathrm{C}$ overnight. Bacterial cells collected by centrifugation were washed twice with water and were resuspended in distilled water to a final density of $10^{9} \mathrm{CFU} / \mathrm{ml}$, for inoculating plants. P. syringae pv. tomato DC3000 (Whalen et al. 1991) was grown in $\mathrm{KB}$ medium supplemented with rifampicin $(50$ $\mathrm{ug} / \mathrm{ml}$ ) at $30^{\circ} \mathrm{C}$ for $48 \mathrm{~h}$. Cells collected by centrifugation were washed twice with distilled water and were resuspended in 10 $\mathrm{mM} \mathrm{MgSO}_{4}$, to a final density of $10^{8} \mathrm{CFU} / \mathrm{ml}$ for dipping inoculation of Arabidopsis.

For the detection of endophytic population of bacteria, root samples were washed with distilled water to remove attached soil and then were surface-sterilized as described above. Surface-sterilized roots $(1 \mathrm{~g})$ were mixed with $4 \mathrm{ml}$ of phosphate buffer (0.1 M, pH 7.0) and were ground with a mortar and pestle. Ground samples were serially diluted with distilled water and spread on a plate to calculate the bacterial population.

\section{Bioassay of plant growth promotion and ISR by $P$. fluorescens FPT9601-T5 colonization.}

Arabidopsis plants were inoculated with $P$. fluorescens FPT9601-T5 by immersing the roots in the bacterial suspen- sion for $10 \mathrm{~min}$ when plants were transplanted from MS medium to soil (discussed above). Plant growth was evaluated by counting the number of leaflets and weighing each one. For the plant growth assay, 11 plants were used for each treatment. To evaluate induced resistance, plants were challenge-inoculated three weeks after $P$. fluorescens FPT9601-T5 inoculation by dipping entire leaf rosettes into $P$. syringae DC3000 suspension in $10 \mathrm{mM} \mathrm{MgSO}_{4}$ with $0.01 \%$ (vol/vol) Silwett L-77, as described by Kunkel and associates (1993). Based on the area with visible symptoms in an Arabidopsis leaflet, the following five disease grades were used: 0 , no symptoms; 1 , symptoms in $\leq 10 \%$ of the leaflet; 2,10 to $50 \%$; $3,>50 \%$; and $4,100 \%$ (Fig. 2A). The disease index was calculated with the following equation: disease index $(\%)=[(\mathrm{N} 0 \times 0+\mathrm{N} 1 \times 1+$ $\mathrm{N} 2 \times 2+\mathrm{N} 3 \times 3+\mathrm{N} 4 \times 4) / 4 \times(\mathrm{N} 0+\mathrm{N} 1+\mathrm{N} 2+\mathrm{N} 3+\mathrm{N} 4)] \times$ 100 , with $\mathrm{N}=$ number of leaflets at each stage of disease grade. At least six Arabidopsis plants were used for each treatment in this assay.

\section{RNA extraction and microarray analysis.}

Total RNA was extracted from shoots of FPT9601-T5treated and untreated plants. Frozen shoots (approximately 0.5 g) were homogenized with a mortar and pestle in liquid $\mathrm{N}_{2}$. The ground powder was transferred to a polypropylene tube, and $5 \mathrm{ml}$ of TriZol reagent (Invitrogen, Tokyo) prewarmed to $80^{\circ} \mathrm{C}$ was added. The homogenates were shaken with vortex for $30 \mathrm{~s}$, and plant debris was pelleted by centrifugation $(10,000 \times g)$ for $10 \mathrm{~min}$ at $4^{\circ} \mathrm{C}$. Chloroform-isoamylalchol $(24: 1)(2 \mathrm{ml})$ was added to the supernatant and was centrifuged for $10 \mathrm{~min}$ at $4^{\circ} \mathrm{C}$ after mixing. Total RNA was precipitated from the aqueous phase with $0.6 \times$ volume of isopropanol by centrifugation $(10,000 \times g)$ at $4{ }^{\circ} \mathrm{C}$ for $10 \mathrm{~min}$. The pellet was washed with $70 \%$ ethanol, dried, and then was dissolved in an appropriate volume of distilled water treated with diethyl pyrocarbonate. The RNA samples were further purified using RNeasy mini plant kit (Qiagen, Valencia, CA, U.S.A.) for microarray analysis. RNA quality was assessed by agarose gel electrophoresis and spectrophotometry.

For microarray analysis, total RNA was processed for use on Affymetrix Arabidopsis genome GeneChip arrays according to the manufacturer's protocol. In brief, 10 ug of total RNA was used in a reverse transcription reaction to generate first-strand cDNA, using the SuperScript choice system (Invitrogen) with oligo $(\mathrm{dT})_{24}$ primer fused to T7 RNA polymerase promoter. After second-strand synthesis, biotin-labeled target complementary RNA (cRNA) was prepared using the BioArray high-yield RNA transcript labeling kit (Enzo Biochem, New York) in the presence of biotinylated UTP and CTP. After purification and fragmentation, $15 \mathrm{ug}$ of cRNA was used in a 300-ul hybridization mixture containing added hybridization controls. A total of $200 \mu \mathrm{l}$ of the mixture was hybridized on arrays for $16 \mathrm{~h}$ at $45^{\circ} \mathrm{C}$. Standard posthybridization wash and double-stain protocols were used on an Affymetrix GeneChip fluidics station 450. Arrays were scanned on an Affymetrix GeneChip scanner 2500 .

\section{RT-PCR.}

Total RNA was isolated as described above. Total RNA used for RT-PCR verification was obtained from plants that were grown independently from those used to isolate RNA for microarray analysis. After treatment with RNase-free DNase followed by phenol extraction and ethanol precipitation, total RNA was reverse transcribed in a $20-\mu \mathrm{l}$ reaction using ReverTra Ace (Toyobo, Tokyo) with the oligo $(\mathrm{dT})_{15}$ primer. For PCR amplification, $1 \mu \mathrm{l}$ of $5 \times$ diluted RT mix was used as a template. The PCR reaction was carried out in $20 \mu \mathrm{l}$ with 0.5 unit of rTaq DNA polymerase (Toyobo), $1.2 \mathrm{mM} \mathrm{MgCl}_{2}$, and $20 \mathrm{pmol}$ of 
each primer. The PCR program was as follows: $10 \mathrm{~min}$ at $94^{\circ} \mathrm{C}, 25$ cycles of $45 \mathrm{~s}$ at $94^{\circ} \mathrm{C}, 45 \mathrm{~s}$ at the optimal annealing temperature $\left(50\right.$ to $65^{\circ} \mathrm{C}$ ), and $45 \mathrm{~s}$ at $72^{\circ} \mathrm{C}$, followed by 10 min at $72^{\circ} \mathrm{C}$. Sets of gene-specific primers used were as follows:

At2g15890-F: TGGTTTACCAAAATCTGAACAAGA

At2g15890-R: CCGCGTAGTACTATAATAGGCACA

At3g60770-F: GCGCAGCAGCAGCCGTAAGAAAGA

At3g60770-R: ACGGGTGGGAGCTTCTTGGTCTTCT

At5g20250-F: GGTACGCTTCGCAATTCCCGGTTTA

At5g20250-R: CGCGTCCCAAGTGCACCATCCGAAG

At3g26740-F: AAGTAATCAGTGGATACGCTTGTTC

At3g26740-R: ATTCTTGTGTAAAACCCAAAACATC

actF: GATATGGAAAAGATCTGGCATCAC

actR: TCATACTCGGCCTTGGAGATCCAC.

\section{ACKNOWLEDGMENTS}

We are grateful to M. Aino, Hyogo Prefectural Agricultural Institute, for valuable suggestions. This work is partly supported by grants from the Japan Society for the Promotion of Science (grant numbers 99L01205 and 11695074).

\section{LITERATURE CITED}

Aino, M., Maekawa, Y., Mayama, S., and Kato H. 1997. Biocontrol of bacterial wilt of tomato by producing seedlings colonized with endophytic antagonistic pseudomonas. Pages 120-123 in: Proceedings of the 4th International Workshop on PGPR. A. Ogoshi, K, Kobayashi, Y. Homma, F. Kodama, N. Kondo, S. Akino, eds. Nakanishi Printing, Sapporo, Japan.

Bakker, P., Ran, L. X., Pieterse, C. M. J., and van Loon, L. C. 2003. Understanding the involvement of rhizobacteria-mediated induction of systemic resistance in biocontrol of plant diseases. Can. J. Plant Pathol. 25:5-9.

Bartsev, A. V., Deakin, W. J., Boukli, N. M., McAlvin, C. B., Stacey, G., Malnoe, P., Broughton, W. J., and Staehelin, C. 2004. NopL, an effector protein of Rhizobium sp. NGR234, thwarts activation of plant defense reactions. Plant Physiol. 134:871-879.

Bashan, Y., Ream, Y., Levanony, H., and Sade. A. 1989. Nonspecific responses in plant growth, yield, and root colonization of noncereal crop plants to inoculation with Azospirillum brasilense. Can. J. Bot. 67:1317-1324.

Busam, G., Junghanns, K. T., Kneusel, R. E., Kassemeyer, H. H., and Matern, U. 1997. Characterization and expression of caffeoyl-coenzyme A 3-O-methyltransferase proposed for the induced resistance response of Vitis vinifera L. Plant Physiol. 115:1039-1048.

Cartieaux, F., Thibaud, M. C., Zimmerli, L., Lessard, P., Sarrobert, C., David, P., Gerbaud, A., Robaglia, C., Somerville, S., and Nussaume, L. 2003. Transcriptome analysis of Arabidopsis colonized by a plantgrowth promoting rhizobacterium reveals a general effect on disease resistance. Plant J. 36:177-188.

Catala, C., Rose, J. K., and Bennett, A. B. 1997. Auxin regulation and spatial localization of an endo-1,4- $\beta$-D glucanase and a xyloglucan endotransglycosylase in expanding tomato hypocotyls. Plant J. 12:417-426.

Charon, C., Johansson, C., Kondorosi, E., Kondorosi, A., and Crespi, M. 1997. ENOD40 induces differentiation and division of root cortical cells in legumes. Proc. Natl. Acad. Sci. U.S.A. 94:8901-8906.

De Meyer, G., Audenaert, K., and Höfte, M. 1999. Pseudomonas aeruginosa 7NSK2-induced systemic resistance in tobacco depends on in planta salicylic acid accumulation but is not associated with PR1a expression. Eur. J. Plant Pathol. 105:513-517.

Favery, B., Complainville, A., Vinardell, J. M., Lecomte, P., Vaubert, D., Mergaert, P., Kondorosi, A., Kondorosi, E., Crespi, M., and Abad, P. 2002. The endosymbiosis-induced genes ENOD4O and CCS52 $a$ are involved in endoparasitic-nematode interactions in Medicago truncatula. Mol. Plant-Microbe. Interact.15:1008-1013.

Glick, B. B. 1994. The enhancement of plant growth by free-living bacteria. Can. J. Microbiol. 41:481-488.

Guenther, J. F., Chanmanivone, N., Galetovic, M. P., Wallace, I. S., Cobb, J. A., and Roberts, D. M. 2003. Phosphorylation of soybean nodulin 26 on serine 262 enhances water permeability and is regulated developmentally and by osmotic signals. Plant Cell 15:981-91.

Handelsman, J., and Stabb, E. V. 1996. Biocontrol of soilborne plant pathogens. Plant Cell 8:1855-1869.

Hungria, M., and Stacey, G. 1997. Molecular signals exchange between host plants and rhizobia: Basic aspects and potential application in agriculture. Soil Biol. Biochem.29:819-830.

Iavicoli, A., Boutet, E., Buchala, A., and Metraux, J. P. 2003. Induced systemic resistance in Arabidopsis thaliana in response to root inoculation with Pseudomonas fluorescens CHA0. Mol Plant-Microbe Interact. 16:851-858.

Jones, L., Ennos, A. R., and Turner, S. R. 2001. Cloning and characterization of irregular xylem4 (irx4): A severely lignin-deficient mutant of Arabidopsis. Plant J. 26:205-216.

Kapulnik, Y. 1996. Plant growth promotion by rhizosphere bacteria. Pages 769-781 in: Plant Roots: The Hidden Half. Y. Waisel, A. Eshel, and U. Kafkafi, eds. Marcel Dekker, New York.

Kunkel, B. N., Bent, A. F., Dahlbeck, D., Innes, R. W., and Staskawicz, B. J. 1993. RPS2, an Arabidopsis disease resistance locus specifying recognition of Pseudomonas syringae strains expressing the avirulence gene avrRpt2. Plant Cell 5:865-75.

Ma, W., Penrose, D. M., and Glick, B. R. 2002. Strategies used by rhizobia to lower plant ethylene levels and increase nodulation. Can. J. Microbiol. 48: 947-954.

Maleck, K., Levine, A., Eulgem, T., Morgan, A., Schmid, J., Lawton, K. A., Dangl, J. L., and Dietrich, R. A. 2000. The transcriptome of Arabidopsis thaliana during systemic acquired resistance. Nat. Genet. 26:403-410.

Meinke, D. W., Cherry, J. M., Dean, C., Rounsley, S. D., and Koornneef, M. 1998. Arabidopsis thaliana: A model plant for genome analysis. Science 282 662-682

Mithöfer, A. 2002. Suppression of plant defence mechanisms in rhizobialegume interactions. Trends Plant Sci. 7: 440-444.

Murashige, T., and Skoog, F. 1962. A revised medium for rapid growth and bioassays with tobacco tissue culture. Physiol. Plant.15:473-479.

Pieterse, C. M. J., Van Wees, S. C. M., Hoffland, E., Van Pelt, J. A., and Van Loon, L. C. 1996. Systemic resistance in Arabidopsis induced by biocontrol bacteria is independent of salicylic acid and pathogenesis related gene expression. Plant Cell 8:1225-1237.

Pieterse, C. M. J, Van Wees, S. C. M., Van Pelt, J. A., Knoester, M., Laan, R., Gerrits, H., Weisbeek, P. J., and van Loon, L. C. 1998. A novel signaling pathway controlling induced systemic resistance in Arabidopsis. Plant Cell 10:1571-1580.

Pieterse, C. M. J., van Pelt, J. A., Ton, J., Parchmann, S., Mueller, M. J., Buchala, A. J., Métrsux, J. P., and van Loon, L. C. 2000. Rhizobacteriamediated induced systemic resistance (ISR) in Arabidopsis requires sensitivity to jasmonate and ethylene but is not accompanied by an increase in their production. Physiol. Mol. Plant Pathol. 57:123-134.

Ross, A. F. 1961. Systemic acquired resistance induced by localized virus infections in plants. Virology 14:340-358.

Schenk, P. M., Kazan, K., Wilson, I., Anderson, J. P., Richmond, T., Somerville, S. C., and Manners, J. M. 2000. Coordinated plant defense responses in Arabidopsis revealed by microarray analysis. Proc. Natl. Acad. Sci. U.S.A. 97:11655-11660.

Schippers, B. 1992. Prospects for management of natural suppressiveness to control soilborne pathogens. Pages 21-34 in: Biological Control of Plant Diseases, Progress and Challenges for the Future, NATO ASI Series, Series A: Life Sciences, Vol. 230. E. C. Tjamos, G. C. Papavizas, and R. J. Cook, eds. Plenum Press, New York.

Simon, G. M., and Chua, N. H. 1999. Interactions and intersections of plant signaling pathways. J. Mol. Biol. 293:219-234.

Taguchi, G., Yazawa, T., Hayashida, N., and Okazaki, M. 2001. Molecular cloning and heterologous expression of novel glucosyltransferases from tobacco cultured cells that have broad substrate specificity and are induced by salicylic acid and auxin. Eur. J. Biochem. 268:4086-4094.

Thomashaw, L. S., and Weller, D. M. 1995. Current concepts in the use of introduced bacteria for biological control: Mechanisms and antifungal metabolites. Pages 187-235 in: Plant-Microbe Interactions, Vol. 1, G. Stacey and N. Keen, eds. Chapman and Hall, New York.

Timmusk, S., and Wagner, E. G. H. 1999. The plant-growth-promoting rhizobacteria Paenibacillus polymyxa induces changes in Arabidopsis thaliana gene expression: A possible connection between biotic and abiotic stress responses. Mol. Plant-Microbe Interact.12:951-959.

Van Loon, L. C., Bakker, P., and Pieterse, C. M. J. 1998. Systemic resistance induced by rhizosphere bacteria. Annu. Rev. Phytopathol. 36:453-483.

Van Rhijn, P., Fang, Y., Galili, S., Shaul, O., Atzmon, N., Wininger, S., Eshed, Y., Lum, M., Li, Y., To, V., Fusishige, N., Kapulnik, Y., and Hirsch, A. M. 1997. Expression of early nodulin genes in alfalfa mycorrhizae indicates that signal transduction pathways used in forming arbuscular mycorrhizae and Rhizobium-induced nodules may be conserved. Proc. Natl. Acad. Sci. U.S.A. 94:5467-5472.

Van Rhijn, P., and Vanderleyden, J. 1995. The Rhizobium-plant symbiosis. Microbiol Rev. 59:124-42.

Van Wees, S. C. M., Luijendijk, M., Smoorenburg, I., van Loon, L. C., 
and Pieterse, C. M. J. 1999. Rhizobacteria-mediated induced systemic resistance (ISR) in Arabidopsis is not associated with a direct effect on expression of known defense-related genes but stimulates the expression of the jasmonate-inducible gene Atvsp upon challenge. Plant Mol. Biol. 41:537-549.

Van Wees, S. C., Pieterse, C. M., Trijssenaar, A., Van Westende, Y. A., Hartog, F., and Van Loon, L. C. 1997. Differential induction of systemic resistance in Arabidopsis by biocontrol bacteria. Mol. Plant-Microbe Interact. 10:716-724.

Verhagen, B. W., Glazebrook, J., Zhu, T., Chang, H.-S., van Loon, L. C., and Pieterse, C. M. J. 2004. The transcriptome of rhizobacteria-induced systemic resistance in Arabidopsis. Mol. Plant-Microbe Interact. 17:895-908.

Wang, R., Mamoru, O., Xing, X., and Crawford, N. M. 2003. Microarray analysis of the nitrate response in Arabidopsis roots and shoots reveals over 1,000 rapidly responding genes and new linkages to glucose, trehalose-6-phosphate, iron, and sulfate metabolism. Plant Physiol. 132:556-567.

Ward, E. R., Uknes, S. J., Williams, S. C., Dincher, S. S., Wiederhold, D. L., Alexander, D. C., Ahl-Goy, P., Metraux, J. P., and Ryals, J. A. 1991. Coordinate gene activity in response to agents that induce systemic acquired resistance. Plant Cell 3:1085-1094.
Whalen, M., Innes, R., Bent, A., and Staskawicz, B. 1991. Identification of Pseudomonas syringae pathogens of Arabidopsis thaliana and a bacterial gene determining avirulence on both Arabidopsis and soybean. Plant Cell 3:49-59.

Yang, Q., Trinh, H. X., Imai, S., Ishihara, A., Zhang, L., Nakayashiki, H., Tosa, Y., and Mayama, S. 2004. Analysis of the involvement of hydroxyanthranilate hydroxycinnamoyltransferase and caffeoyl-CoA 3-Omethyltransferase in phytoalexin biosynthesis in oat. Mol. PlantMicrobe Interact. 17:81-89.

Zhang, L., Tosa, Y., Nakayashiki, H., and Mayama, S. 2000. Antibiotic 2 4-diacetylphloroglucinol played an important role in biocontrol ability of Pseudomonas fluorescens FPT9601. Ann. Rep. Interdiscipl. Res. Inst. Environ. Sci. 19:151-163.

\section{AUTHOR-RECOMMENDED INTERNET RESOURCES}

Affymetrix microarray probe set ID files: ftp://tairpub:tairpub@ftp. Arabidopsis.org/home/tair/Microarrays/Affymetrix/

Affymetrix statistical algorithms reference guide: www.affymetrix.com/ support/technical/technotes/statistical_reference_guide.pdf

The MIPS Arabidopsis database: mips.gsf.de/proj/thal/db/index.html 